\title{
Study on Crop Performance and its Related Physiological Parameters of Certain Commercial Jasmine Varieties during Lean Flowering Season
}

\author{
Monika Patel $^{1 *}$, M. Ganga ${ }^{2}$ and M. Jawaharlal ${ }^{3}$ \\ ${ }^{1}$ Department of Floriculture and Landscaping, Punjab Agricultural University, \\ Ludhiana, Punjab, India \\ ${ }^{2}$ Horticultural Research Station, Ooty, Tamil Nadu Agricultural University, \\ Coimbatore, Tamil Nadu, India \\ ${ }^{3}$ Horticulture College and Research Institute, Tamil Nadu Agricultural University, \\ Coimbatore, Tamil Nadu, India \\ *Corresponding author
}

A B S T R A C T

\begin{tabular}{|c|}
\hline Keywords \\
\hline $\begin{array}{l}\text { Jasminum spp., } \\
\text { Commercial } \\
\text { varieties, Crop } \\
\text { performance, Lean } \\
\text { flowering season. }\end{array}$ \\
\hline Article Info \\
\hline $\begin{array}{l}\text { Accepted: } \\
04 \text { October } 2017 \\
\text { Available Online: } \\
10 \text { December } 2017\end{array}$ \\
\hline
\end{tabular}

Keywords

Jasminum spp.,

Commercial

Lean

Article Info

Accepted:

Available Online:

10 December 2017
Assessment of crop performance and its related physiological parameters are important for commercial cultivation as well as crop improvement programme point of view. The unique white fragrant flowering crop jasmine is a highly valued ornamental plant for home gardens and commercial cultivation in many warm temperate, tropical and subtropical countries of the world. Although many varieties of Jasminum species are cultivated in Tamil Nadu as well as in India, but Ramanathapuram Gundumalli, Madanban, Ramabanam, Single Mohra, CO.1 Mullai, Parimullai and CO.1 Pitchi are largely cultivated. There is less or no scientific evidence available on crop performance during lean flowering season. Highest plant height, plant spread, number of branches and flower bud yield per plant were recorded in CO. 1 Pitchi. All the vegetative and yield parameters had direct correlation with the total chlorophyll content and relative water content. Highest total chlorophyll content $\left(1.538 \mathrm{mg} \mathrm{g}^{-1}\right)$ and relative water content $(86.50 \%)$ were recorded in CO. 1 Pitchi. It is important to study the qualitative and quantitative flower quality parameters to maintain the uninterrupted supply chain during lean flowering period.

\section{Introduction}

Jasmine (Jasminum spp.) is one of the oldest traditional flowering crop belongs to the family Oleaceae and this genus has more than 200 species (Dickey, 1970). It is a native plant of South and Southeast Asia and is distributed in warm temperate, tropical and subtropical countries of the world. But more number of species is found in the regions of India, Malaysia and China (Anon., 1959). The attractive foliage and fragrant white flowers make it a highly valued commercial crop in
India, Central Asia, Afghanistan, Iran, Nepal, Thailand, China, Sri Lanka and the Philippines for its fresh flowers. Commercial cultivation is confined to three species, viz., Jasminum sambac, Jasminum auriculatum and Jasminum grandiflorum (Green and Miller, 2009).

In India it is mostly cultivated in South India. Jasmine flowers are exported to countries like Singapore, Malaysia, Japan, UK, USA, UAE 
and Eastern European countries. During lean flowering season flower export is hampered due to shortage of flowers. It is important to study the basic growth and its related physiological parameters to understand the physiology behind the growth and yield during lean flowering season. This study can also identify the best suitable variety for lean season growing both for commercial production and crop improvement programmes.

\section{Materials and Methods}

This study was conducted on two year old jasmine plants present in Botanic Garden, Department of Floriculture and Landscaping, Tamil Nadu Agricultural University, Coimbatore during lean flowering season from 2012 to 2013.

September to October, October to December and November are the lean flowering seasons for $J$. sambac, $J$. auriculatum and $J$. grandiflorum respectfully. Plant height $(\mathrm{cm})$, Plant spread $(\mathrm{cm})$, Number of primary branches per plant $(\mathrm{cm})$ and Number of secondary branches per plant $(\mathrm{cm})$ were studied for assessment of vegetative parameters of plants where as Flower bud yield per plant (g) was studied for assessment of crop yield. Total chlorophyll content $(\mathrm{mg}$ $\mathrm{g}^{-1}$ ) and Relative water content (\%) were studied to understand the physiology behind the growth and yield of crop.

Total chlorophyll contents were estimated in a fully expanded leaf by adopting the procedure of Yoshida et al., (1971). The relative water content of leaves was calculated as per the method of Barrs and Weatherley (1962). The statistical design adopted was RBD. Statistical analysis was done by using AGRES software package and the CD values were worked out for five percent (0.05) probability.

\section{Results and Discussion}

\section{Vegetative parameters}

A significant variation was noticed among the varieties with regard to plant height, plant spread, number of primary branches per plant and number of secondary branches per plant under open field condition.

These variations may be due to the fact that the varieties belong to three different species and even within a single species, the varieties are from diversified origin.

Plant height is one of the fundamental characters which is taken into account for crop performance of genotypes. In the present study, among the genotypes, CO.1 Pitchi $(105.24 \mathrm{~cm})$ was the tallest and Ramanathapuram Gundumalli $(82.50 \mathrm{~cm})$ was the shortest (Table 1).

Being a genetically controlled factor, plant height varied among the genotypes. Similar variation in plant height due to genotypes was also observed in chrysanthemum (Dilta et al., 2005).

Branches per plant is also an important criteria related to crop performance because the branches determine important parameters including the plant spread, flower bearing shoots, etc.

The variety CO.1 Pitchi recorded the maximum plant spread and number of branches per plant (Table 1). The difference in the number of branches over the rest of the genotypes could be due to the influence of genetic makeup of the genotypes and environmental modulations.

This finding is in accordance with the earlier observations of Rangaswami (1989) in Jasminum spp. 
Table.1 Assessment of vegetative, yield and physiological parameters of certain commercial jasmine varieties during lean flowering season

\begin{tabular}{|c|c|c|c|c|c|c|c|c|}
\hline $\begin{array}{l}\text { S. } \\
\text { No. }\end{array}$ & Varieties & $\begin{array}{l}\text { Plant height } \\
(\mathrm{cm})\end{array}$ & $\begin{array}{l}\text { Plant spread } \\
(\mathrm{cm})\end{array}$ & $\begin{array}{l}\text { Number of } \\
\text { primary } \\
\text { branches per } \\
\text { plant }\end{array}$ & $\begin{array}{l}\text { Number of } \\
\text { secondary } \\
\text { branches per } \\
\text { plant }\end{array}$ & $\begin{array}{l}\text { Flower bud } \\
\text { yield per } \\
\text { plant }(\mathrm{g})\end{array}$ & $\begin{array}{l}\text { Total chlorophyll } \\
\text { content }\left(\mathrm{mg} \mathrm{g}^{-1}\right)\end{array}$ & $\begin{array}{l}\text { Relative } \\
\text { water } \\
\text { content }(\%)\end{array}$ \\
\hline 1. & $\begin{array}{c}\text { Ramanathapuram } \\
\text { Gundumalli } \\
\text { (Jasminum sambac) }\end{array}$ & 82.50 & 61.10 & 5.40 & 32.20 & 195.75 & 1.392 & 85.44 \\
\hline 2. & $\begin{array}{c}\text { Madanban } \\
\text { (Jasminum sambac) }\end{array}$ & 88.89 & 84.60 & 6.20 & 34.20 & 104.27 & 1.321 & 83.45 \\
\hline 3. & $\begin{array}{c}\text { Single Mohra } \\
\text { (Jasminum sambac) }\end{array}$ & 86.62 & 67.80 & 5.40 & 23.60 & 80.06 & 1.213 & 81.10 \\
\hline 4. & $\begin{array}{c}\text { Ramabanam } \\
\text { (Jasminum sambac) }\end{array}$ & 83.52 & 85.25 & 6.00 & 33.00 & 116.99 & 1.186 & 84.78 \\
\hline 5. & $\begin{array}{c}\text { CO.1 Mullai } \\
\text { (Jasminum auriculatum) }\end{array}$ & 84.80 & 88.13 & 7.00 & 42.10 & 109.40 & 1.118 & 83.52 \\
\hline 6. & $\begin{array}{c}\text { Parimullai } \\
\text { (Jasminum auriculatum) }\end{array}$ & 87.34 & 103.25 & 12.00 & 48.50 & 95.60 & 1.138 & 81.91 \\
\hline 7. & $\begin{array}{c}\text { CO.1 Pitchi } \\
\text { (Jasminum grandiflorum) }\end{array}$ & 105.24 & 203.15 & 12.50 & 67.70 & 213.81 & 1.538 & 86.50 \\
\hline & $\begin{array}{c}\mathrm{SEd} \\
\mathrm{CD}(\mathrm{P}=0.05)\end{array}$ & $\begin{array}{l}0.633 \\
1.379\end{array}$ & $\begin{array}{l}3.444 \\
7.505\end{array}$ & $\begin{array}{l}0.225 \\
0.491\end{array}$ & $\begin{array}{l}1.156 \\
2.519\end{array}$ & $\begin{array}{l}0.140 \\
0.305\end{array}$ & $\begin{array}{l}0.012 \\
0.026\end{array}$ & $\begin{array}{l}0.115 \\
0.252\end{array}$ \\
\hline
\end{tabular}


Fig.1 Flower bud yield per plant (g) of jasmine varieties

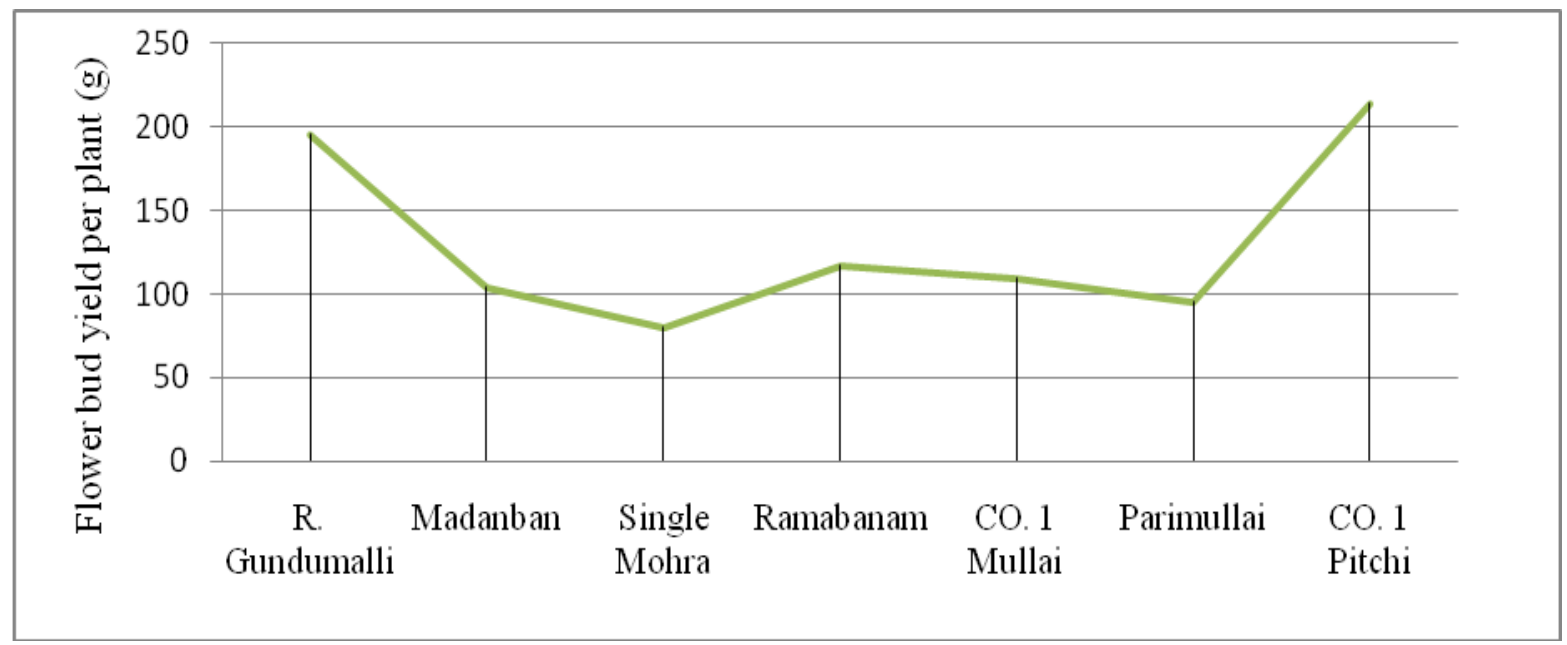

\section{Yield parameters}

In the present study, significant variations were observed for yield of flowers per plant under field condition. The highest and second highest flower bud yield per plant was found in CO.1 Mullai (213.81 g) and Parimullai (195.75 g) respectively (Table 1, Fig.1). Similar observations have were made earlier by Raman et al., (1969) in varieties of the four commercial species ( $J$. sambac, $J$. auriculatum, $J$. grandiflorum and $J$. pubescence) as well as in few other Jasminum spp. Similar results were obtained earlier by Seetharamu et al., (2002) in these three species of jasmine. The varietal differences in yield potential may be due to the additive gene effect (Hemalata et al., 1992).

\section{Physiological parameters}

In the present study, chlorophyll content of plants varied significantly among the varieties (Table 1). Highest chlorophyll content noted in CO.1 Pitchi. Chlorophyll content has direct correlation with either vegetative growth or flower yield per plant. Similar report was reported by Gupta and Dutta (2005) in chrysanthemum and Jennoah (2012) in Ramanathapuram Gundumalli of J. sambac.
Photosynthetic efficiency directly influences the yield of a plant and it is positively correlated with the relative water content of the plant. In the present study, RWC was highest in CO.1 Pitchi, followed by Ramanathapuram Gundumalli and it was lowest in Single Mohra (Table 1). A similar trend was observed for flower bud yield. The relative water content was highest at CO.1 Pitchi.

Photosynthetic efficiency is directly correlated with the chlorophyll content and relative water content of the plant. Variations noticed among the varieties were may be due to the genetic makeup or may be due to the differential effect of the climate over different species and varieties. In the present study vegetative, yield and physiological parameters of certain commercial jasmine varieties during lean flowering season were studied and it will help further in modification of crop performance during this season. If we can able to modify the growing conditions as like in peak flowering season, it may subsequently improve the yield. Results of the present study helped us to understand the potential variety for the lean flowering season and physiology behind the growth and yield of jasmine crop. 


\section{References}

Anonymous. 1959. Encylopaedia Britannica, Encyclopaedia Britannica Ltd., Chicago.

Barrs, H. D. and Weatherley, P. E. 1962. A reexamination of the relative turgidity technique for estimating water deficit in leaves. Aust. J. Biol. Sci., 15: 413-428.

Dickey, R. D. 1970. In: Flowering Vines of the World (Ed. E. A. Meninger), Heartside Press Inc., New York.

Dilta, B. S., Sharma, Y. D. and Verma, V. K. 2005. Evaluation of chrysanthemum cultivars under subtropical region of Himachal Pradesh, J. Ornamental Hort., 8(2): 149-151.

Green, P. and Miller, D. 2009. The genus Jasminum in cultivation, Kew Publishing, Royal Botanic Gardens, Kew.

Gupta, V.N. and Dutta, S.K. 2005. Morphological and chemical characterization of thirty small flowered chrysanthemum cultivars. J. of Ornamental Hort., 8(2): 91-95.
Hemalata, B., Patil, A. A. and Nalwadi, U. G. 1992. Variability studies in chrysanthemum. Prog. Hort. 24(1-2): 55-59.

Jennoah, B. 2012. Standardization of techniques for off-season flowering in jasmine species under polyhouse. Ph.D. Thesis submitted to Tamil Nadu Agricultural University, Coimbatore-3.

Raman, K. R., Shanmugham, A. and Shah, H.A. 1969. Studies on the flowering habits and flower yields of some Jasminum species. South Indian Hort. 17: $18-27$.

Rangaswami, P. and Khader, M. D. A.1989. Growth analysis of Jasminum spp. South Indian Hort., 37(6): 367.

Seetharamu, G. K., Kumar, D. P., Mohan, E. and Heriae, P. S. 2002. Evaluation of different species and varieties of jasmine under hill zone. South Indian Hort. 49: 35-38.

Yoshida, S., D. A., Cock, F. J., and Gomez, K. A. 1971. Laboratory Manual for Physiological Studies. IRRI, Philippines. pp. 144.

\section{How to cite this article:}

Monika Patel, M. Ganga and Jawaharlal, M. 2017. Study on Crop Performance and its Related Physiological Parameters of Certain Commercial Jasmine Varieties during Lean Flowering Season. Int.J.Curr.Microbiol.App.Sci. 6(12): 40-44. doi: https://doi.org/10.20546/ijcmas.2017.612.005 